\title{
The grab of the world's land and water resources
}

\author{
FRANKLIN OBENG-ODOOM*
}

In this paper, I review recent developments in global political economy and political economy of development that have captured inter alia the attention of agrarian political economists. I do so through the periscope of two recent publications by Fred Pearce, Great Britain's leading eco journalist and an edited volume by Tony Allan, Martin Keulertz, Suvi Sojamo and Jeroen Warner, scholars trained in different disciplines and based at various universities in the UK, the Netherlands, and Finland. The account of the pace, places, and perpetrators, procedures, and problems of this particular agrarian model provides fodder for the further development of a locus classicus on what is happening to the land question in this current moment under the capitalist order, a shorthand for which is 'water and land grab'.

Keywords: Land; development; political economy; water; financial crises.

JEL Classification: O13.

\section{INTRODUCTION}

These books contain a disturbing thesis: The triple crises of capital, in the form of financial meltdown, climate change, and food prices, are creating massive exploitation, expropriation, and forced eviction in the agrarian sector of the global economy. The scale is massive, and the location diverse, as are the victims and perpetrators.

While, many academic papers, NGO reports, media articles, and press releases on the subject abound, it is these two books that have, to date, taken a more indepth and sustained approach to investigating the phenomenon. The Land Grabbers (Pearce, 2012) was the first to be published, but the absence of references to

\footnotetext{
* School of the Built Environment and Asia-Pacific Centre for Complex Real Property Rights, University of Technology, Sydney, Australia. E-mail: Franklin.Obeng-Odoom@uts.edu.au. Submitted: 15/October/2012; Approved: 3/December/2012.
} 
it in the Handbook of Land and Water Grabs in Africa (Allan et al., 2013) which was published later suggests that neither the editors nor the numerous contributors to the Handbook were aware of Fred Pearce' major contribution. This is an important oversight in the Handbook, and perhaps was the reason the editors proclaimed that "[i]t is the most comprehensive publication to date on the new enclosure of Africa's farmland" (Allan et al., 2013, iii, preface). I think it best to consider these books as jointly deserving of the accolade of 'most comprehensive account'. They have different features, but they are complementary rather than competitive.

Pearce is one of Britain's leading investigative eco journalist, and his book benefits from his erudite and engaging writing style. It is accessible, well organised, informed, and personalised. His observations are reported systematically, and his analysis grounded in evidence, although he does not always reference his same way academics usually do it. The book is rich in personal and informed details of specific cases of land grabbing around the world, from poorer (e.g., Sudan) to rich but relatively small countries (e.g., Saudi Arabia), and then the richer and bigger countries (e.g., Australia). The book is the product of Pearce' field travels, interviews, and engagement with people who have facilitated, resisted, or actually grabbed land, and water. The Land Grabbers is divided into 27 chapters, in six parts, looking at land grabbing across the world. There are blank pages after each chapter for readers to make notes, so this is a very user friendly book.

The Handbook is more 'academic', and not written in a style as accessible as Pearce' book. It is an edited collection, to be sure, with writers from different backgrounds and academic and professional styles, so some writers are a lot more accessible than others. It contains an impressive blend of more seasoned writers on African political economy such as Padraig Carmody and Liz Alden Wiley and younger, but known, writers on land grab such as Jessica Chu of the School of Oriental and African Studies. It is organised in five parts, respectively looking at the history of land grabs (pp. 9 -88), investors' profiles and investments (pp. 89-207), the political economy of land and water grabs (pp. 221-334), the environment (pp. 335-418), and livelihoods (pp. 419-468). The book has a comprehensive index (pp. 469-488) to guide readers and, as with other edited volumes, a succinct description of the backgrounds and interests of the editors and the contributors (pp. xiv-xxii) to enable readers to put a 'face' to the various accounts in the book.

The editors of the Handbook, a creative blend of scholars at different stages in their career, made a courageous attempt to contextualise the various contributions, but were not entirely successful. For example, the aim of the Handbook is stated by the editors as follows:

This handbook has been put together to help investors, farmers, traders and the other food supply chain players understand how foreign direct investment in African water and land resources could impact food availability and therefore food commodity prices (...) The chapters of this book have been assembled now because there is a need on the part 
of would-be investors to understand the history of previous phases of inward investment in land and water in Africa. (Allan et al., 2013, p. 6)

Yet, many contributions do not fit this vision. Indeed, the idea of food as 'commodity' is severely rebuked by some contributors, while others do not regard land grab as 'foreign direct investment'. In fairness to the editors, they do acknowledge that the chapters and concerns of the contributors are broad ranging, but their suggestion that the book is written to help the investor or supply a knowledge gap for investment is inconsistent with many of the chapters in the book. Indeed, some of the chapters talk about struggles and how they can be sustained (e.g., Allan et al., 2013, pp. 456-468), and the limitations of investor or investment driven regulations, from the perspective of smallholders and national governments (e.g., Allan et al., 2013, pp. 286-298).

Another quibble is that, while I found the division of the book into various parts useful, overall, it was hard to see how the descriptors were chosen. Take the part on political economy, for example. Some of the chapters offer depoliticised analysis, have little to say about capital, power, and distribution, to name but a few features of political economic analysis, so it is not clear why or in what ways they are 'political economic'. Also, one of the chapters in Part III, 'The political economy of land and water grabs' is called 'political economy of land and water grabs' (Allan et al., 2013, pp. 257-272), so again it was unclear to me in what sense the term, political economy was being used. The analysis on class struggle could easily have been in Part III, but it is placed in Part V, Livelihoods. Clearly, there is some arbitrariness in how to draw boundaries. Yet, in my opinion these quibbles are slight, and merely pedantic. Indeed, there are some chapters which aptly live the aim of the book as articulated by the editors, such as "(...) How foreign direct investment can support sustainable intensification" (Allan et al., 2013, pp. 359-375), which is a depoliticised analysis of how best investors can 'help' poor people in Africa.

There is a lot of excellent work done by the editors for which they deserve commendation, and their book, full endorsement. Pulling together this array of contributors and contributions from all over the world, from writers on the topic and in allied areas on such a 'hot' issue is a major achievement. While the book literally stammers in a few parts (e.g., Allan et al., 2013, pp. 311-333) where it is hard to see a contribution, other than matters already stated, and well known it picks up and sustains momentum in most parts. In any case, as I shall discuss below, the book offers deep insights and unearths gray areas in need of further investigation. The explicit focus on water, 'blue' and 'green', substantially expands the ongoing conversation on the land grab phenomenon.

The Land Grabbers and the Handbook of Land and Water Grabs in Africa are a must read. What I attempt to do, from this point on, is to highlight their specific contribution using what I call the ' 6 Ps' - Pace and Places, Perpetrators, Procedures, Problems, Proposals, and Prospects — of land and water grabbing. 


\section{PACE AND PLACES}

Since 2007-8, large tracts of land have been leased to foreign and local interests for periods as long as 99 years. When GRAIN, the global NGO, first broke the news in 2008 around which time Daewoo was negotiating what eventually turned out to be an abortive land deal in Madagascar (Borras and Franco, 2012), the initial estimates given were 2.5 million hectares of land. Subsequently, the World Bank updated the figure to 56 million hectares around 2010. Now the figure seems to be around 71 million hectares (International Land Coalition, 2012). The statement of intent about obtaining large tracts of land, as opposed to actual leases is, however, in the region of 203 million hectares of land. These figures are likely to be conservative because a substantial amount of land deals go unreported, are shrouded in secrecy, and do not make it to any central body to collate the figures. Furthermore, some of the countries offering deals have done no proper scientific mapping. Thus, Pearce (2012, p. 45) recounts, how they quote unfounded claims. In the case of South Sudan, for example, one deal was said to be for 600,000 acres in Lainya, but crosschecking shows that the county of Lainya is itself only 340,000 hectares big.

In addition to 'physical land', water has also been grabbed for the purpose of irrigating particular 'grabbed' parcels of land. In Senegal, a 400,000 acre deal to Saudi Arabia is close to River Senegal which will be the source of irrigation (Pearce, 2012, p. 33). In South Sudan, the new government seems to be negotiating a deal to send water to Egypt by preparing to allow Egypt to construct a canal to channel water from the Nile around the giant Sudd Swamp in South Sudan which is the second largest swamp in the world and the home of a great wildlife diversity and pasture. For Egypt, the canal will enable the Nile to deliver more water to it because currently the swamp saps a great deal of water en route to Egypt, a one year journey during which a lot of the water evaporates (Pearce, 2012, p. 49). Generally, under international law, host countries must undertake to provide water to investors as without water investors cannot fully benefit from their investment. In turn, governments may be sued if, in the process of supplying water to their citizens, they are unable to satisfy international private interests (Pearce, 2012, pp. 102-103).

\section{PERPETRATORS}

The identity and methods of the land grabbers vary greatly. Countries, state corporations, private interests, missionaries, NGOs, and universities are all involved. International interests dominate, although local actors are partakers too. Unlike pre 2007-8 land leases, the current lessees come from within and without the West, including from countries such as South Korea, Saudi Arabia, and India which have been prominent in land purchases. 'Traditional' land grabbers such as the UK have remained active too.

The exact role of China, as a perpetrator, seems to be shrouded in some con- 
troversy. Land Portal (2012) suggests that China is one of the leading land grabbers, but this is contradicted by these books. However, the Handbook (Allan et al., 2013, pp. 91-103) contains evidence to contradict such accounts, positing massive Chinese investment in the agrarian sector in Africa. Apparently, China's investment in the agrarian sector is not as huge. To be sure, China has changed its aid policy to become increasingly focused on agriculture in Africa where the Chinese state believes it can contribute a lot by way of technical assistance. So, it might be that China's influence in the sector will increase overtime but for now it is not as widespread as is generally believed. One key feature of Chinese investment in agriculture is that, while increasing population is exerting pressure on national food policy, for the Chinese state it seems it is more of geopolitical influence, control, and relevance in geopolitics that explain its interest in acquiring large tracts of land (Pearce, 2012, pp. 199-205). Still, there are major concerns about conditions of labour in Chineseled agro investments. Even more noteworthy is the seeming top-down idea inherent in the new Chinese policy on aid for the agric sector - a departure from an investment orientation in other sectors where the stated objective more about mutual learning and benefit (Allan et al., 2013, pp. 436-445). This change is disturbing as agriculturalists have long established the importance of bottom-up, and farmer-led approaches or participatory learning and action, as recently demonstrated in Food Security in Africa and Asia: Strategies for Small-Scale Agricultural Development (Bakker, 2011).

While the activities of other perpetrators such as private business people masquerading as religious persons, and eco activists (Pearce, 2012) will appear as no news, the Handbook reveals there is a stratum of land grabbers for whom very little attention has been given in the media, academic papers, and reports. These are rich or relatively well off civil servants, and private entrepreneurs who are based in the city, and urban based companies that grab land in the countryside. These are the 'domestic, urban land grabbers' whose activities are not new in the history of agriculture. What is 'new' is the intensity, the scale, and the size of plots grabbed, since the 2008 crises of capital. One reason for the increase is the opportunity for profit and the rush of foreign capital, but another reason is government encouragement for them to invest in agriculture and 'modernise' the sector. The Handbook describes these dynamics in the case of Mali, Burkina Faso, and Benin (Allan et al., 2013, pp. 146-159).

The two books show that the varying personalities involved in land and water grabbing, are closely associated with the methods used. However, three common approaches have been used to obtain land leases, so far. One, negotiations with central government without local government and local chiefs. Two, negotiations with local chiefs without central and local government and local community and, three, negotiations with central and local government and local elites, include chiefs, but no consultation with other elders in the communities. The triggers or factors influencing success and failure of negotiations are mainly religious affinity, whether title is recognised, and level of development (Schoneveld et al., 2011; Pearce, 2012). Also, rich governments improve their chances of seeking land deals by invest- 
ing in dilapidated infrastructure of poorer countries in return for land. That is evidently, what for a while, was going to happen in Kenya where the government of Qatar was going to build a billion dollar port facility in exchange for a 100,000 acres of land on Lamu Island (Pearce, 2012, p. 36).

The role of the global financial institutions, such as the World Bank, has been shadowy, namely consigned to carrying out studies to identify vacant land. Also, they have favoured the registration of titles to make it easier to trade in land. On the part of investors, the books show that the financial power houses have offered huge loans, others have directly invested, and many more have offered guarantee and investment advice. Glossy magazines have been produced and an aggressive campaign used to encourage people to invest (Allan et al., 2013). How to make sense of all these dynamics - whether to call them 'pro development' or 'anti development' - critically depends on which method or procedures are used for analysis. Again, the two books showcase a range of procedures.

\section{PROCEDURES}

The books apply five main types of analysis, namely ethnography, legal, technocratic, political ecology, and political economy, and historical. Pearce Book might be regarded as using a kind of quasi ethnographic method, as the account is based on his observations as participant or non participant in different land and water grabbing locations, while travelling around the world. This makes his work richer in stories, and personal details. A few of the chapters in the Handbook adopt a similar approach (e.g., Allan et al., 2013, pp. 91-103), but the rest use a political ecology or economy approach. Those that use political ecology seem to look at the issue of land grabbing through the lens of power and how it influences the grab of water and other natural resources, while those employing political economy tend to look, among other things, at power relations, class, global capitalist and how they shape, and constrain land grabbing. Perhaps, the use of political ecology in this context is more effective as it more forcefully draws attention to 'water grabs' which have, relative to land, not obtained careful attention. However, it seems some contributors to the Handbook (e.g., p. 40) thought it better to combine political economy and ecology as the dynamics of land grabbing are wedded to broader political economic processes.

To this end, it was surprising that political economic concepts and lenses such as Karl Polanyi's double movement (Polanyi, 1954 [2001]), the question of land taxation from Henry George (1879 [2006]), and Philip McMichael (e.g., McMichael and Buttel, 1990) and Harriet Friedmann's (e.g., Friedmann, 1982) well known food regime analyses did not get any careful attention. An attempt was made to use 'cycles' to analyse land grabbing (Allan et al., 2013, pp. 243-256), but such cycles these were explained more generally, not really in terms of food production. Admittedly, even the regime analysis needs some adaptation to take into account the dynamics of land and water, as the approach was developed mainly to 
look at food. The current phenomenon, on the other hand, is not only about food, as the books show. It involves bio-fuel crops, water, and timber, not originally captured in the regime analysis.

A historical touch is evident throughout these books, especially in the Handbook. Indeed, it had a section devoted entirely to the history of land grabbing. However, it is not clear whether merely recounting the history of enclosures, especially colonial attempts to 'grab' land constitutes a 'historical method'. More fundamentally, some of the chapters told interesting historical stories (e.g., Allan et al., 2013, pp. 57-70) but their connection to the contemporary experiences were hard to see, other than to say that land grabbing is not new.

A historical method ought to do more than that, in my opinion. At least it ought to demonstrate the strategies and dynamics of how the state has historically played a role in the accumulation of capital, and in what ways that has evolved, how the old order continues to shape agrarian change today and tomorrow, and how the reification of customs, manipulation of customary law, and adoption of Western law as a social good paved the way for the current land and water grabs (TNI, 2012). It is such elements, among others, that use the past to inform the present and the future and correct misrepresentations of today, especially in Africa (Njoh, 2012), that a 'good' historical approach will engender (see, for example, Tuma, 1971; Greif, 1998).

From this perspective, most of the chapters succeeded, but not many of those consigned to part 1 on history, as they merely recounted the history of colonial enclosures and did not connect forcefully to the present. Yet, the contributions in the rest of the Handbook use the historical method effectively. In particular, the last chapter is an exemplar. It showed how the perpetrators land and water grab have historically encountered resistance and continue to do so, thus confronting colonial narratives that cast customary owners of land as acquiescent. That chapter also challenged the oversimplification syndrome that 'culture' and 'community' are a panacea to land grabbing and confronts discourses about how modernisation and titling and indeed law (legal method/approach to analysis) can and do facilitate water and land grabbing. While it does that, it shows the various levels of struggles in the process, and raises the question of what the struggles are all about.

\section{PROBLEMS}

The books are unanimous on the tensions and contradictions of land and water grabbing. They show that the declared motives used to 'sell' the land and water grab idea - mainly offering jobs to local people, taxation revenues to governments, and mechanisation of the entire agricultural sector - have turned out to be wild expectations. That is, some of these benefits have trickled in, in some cases, but they are a drop in the ocean, considering that large communities have had to be moved and large tracts of land offered. Further, in most cases taxes have been waived to attract the perpetrators, so tax revenues are yet to be realised. Fur- 
ther, in situations when jobs have been created, the conditions of the workers have not been considered, or that jobs have been transient. In some cases too, peasants have been turned into wage labourers or that social differentiation has been created among the class of workers, something known among Marxist political economists as 'labour aristocracy'. Owners have been turned to tenants on their own land, for periods sometimes as long as 99 years.

More ominous is the threat to different layers of water property rights for fishers, farmers, and hunters, women and children who depend on water for housework, all these stand threatened with the enclosures of water. Even scarier is that international law will tend to favour investors' rights to water when the issue comes up for arbitration (Pearce, 2012, pp. 102-103). This is why regulating water rights, that is, insisting on the inclusion of water right clauses is likely to trump customary practices and norms about access to and use of water. Indeed, governments, motivated by obtaining more FDIs, are likely to favour commercial deals about water over the free use by indigenous people. And, in such cases international law tend to hold that parties respect the terms of the contract, regardless of the local situation (Allan et al., 2013, p. 288), regardless of whether there is a drought, and regardless of whether there is a humanitarian crisis. Similarly, even in the face of famine in the most desperate country, international investment agreements (IIAs) will hold the terms of the agreements sacrosanct, even if unjust, inhuman, or unkind, as Pearce (2012, p. 103) notes. The books show that the agreements will tend to favour investors anyway, so investment or 'contract water' and land grab are not as good as sometimes claimed. Indeed, the threat of pollution from mechanised farming, and possible cross country conflicts, as a recent study (Rahman, 2012) has shown.

To date, these problems have not been equally borne. Settler migrants, and other minority groups, women, and children, according these books, have suffered disproportionately more. What the books do not carefully show is that, in some cases, investors have also been swindled, so it is not the case that all investors have benefitted. An example is the case of Greenleaf Global Plc which was operating in Ghana and Togo. Investors sunk GBP 8.2 million into land deals with the promise that they would receive a return of about 20 per cent within 12 months when, in fact, no careful prior analysis had been made. Also, the company had claimed it had had a bountiful harvest in 2010 and paid huge returns to investors when, in fact, no such thing had every happened. In the end, the company was rendered insolvent (Insolvency Service, 2012). In fairness to the editors of the Handbook, especially, one chapter (Allan et al., 2013, pp. 146 -159) does indicate that domestic grabbers fail to reap the rewards they expected, but even then, the reason given is one of inexperience not deceit. Yet, such crises among the investor class are isolated. Many pension and hedge fund managers are pouring investment into land and water grab, mainly because the returns are good. On the contrary, a disproportionate share of the cost of grabbing is borne by local people, so how to change the skewed distribution of benefits and costs gets some attention in the two books. 


\section{PROPOSALS}

Here, there is some tension in the books, especially the Handbook. While some seem to suggest that the recognition or formalisation of indigenous rights and hence the compensation of indigenous people if their rights are trampled upon is a panacea (pp. 11-23), others suggest this 'way of seeing' is woefully inadequate because there are many countries the world over (e.g., Ghana and South Sudan) where such formalisation has not stopped, or led to a propitious outcome for the general wellbeing of the people (e.g., Allan et al., 2013, pp. 24-42; pp. 286-296; pp. 57-70).

For Pearce, prioritising small scale farming is the answer to the crises in the agrarian sector. He provides formidable evidence of how small holder farmers in either the urban or rural setting in Africa and Asia, and indeed elsewhere, have produced sustainably - on small plots, using and recycling farm generated resources and marketing the produce locally. Further, he offers evidence on how small scale farming has led to growing incomes of farmers and led to an increase in food production. In urban areas, Pearce shows how the use of urban agriculture can create greater interaction between the city, the peri-urban area, and the countryside. In turn, Pearce advocates the support of smallholders through extension services and subsidies (see Pearce, 2012, pp. 291-301).

Pearce does not show how to move from 'here' to 'there', but the Handbook does. One contributor suggests struggle, Awake! Aluta continue! Not everyone writing for the handbook is in favour of this approach. Others argue that it is not the only way. Alternatives such as contract farming, where the investor contracts with the small farmer to take their land or buy their produce, are posited. Another suggestion is where a rich investor creates an estate and buys off produce from small scale out growers in a so-called 'impact investment'.

A third is a model where the investor leases the land off poor people, or buys their labour and turns them into wage labour, or a combination of these. Other similarly 'practical' suggestions are partnering the community in a private-community partnership. Examples from Tanzania and Sierra Leone are presented to back these claims as successful (Allan et al., 2013, pp. 160-177). However, it would seem that a lot more research will be required to ascertain whether these projects achieve their posited win-win outcomes, especially so when it is hard to describe as 'equal party to a contract' challenging to try to force an agreement between substantially unequal partners (as in a big investor and a poor farmer). While these types of alternatives make land grabbing transparent, they are still land grabbing. And, they tend to facilitate land grabbing, assuming that it must happen (TNI, 2012), when, in fact, in both Sierra Leone (see, for example, Lynch et al., 2012) and Tanzania (see, for example, Dubbeling, 2010) there is formidable evidence that small holder farming is making a tremendous impact on social change. 


\section{PROSPECTS}

A key contribution of these books is that they give clear suggestions of where further research is required. Six of them are particularly pressing. One, the phenomenon of urban domestic elites capturing land requires more study, as the current discussion in the media and academic journals is predominantly on international angles of land and water grabs. It would be interesting to know whether elites partner with investors and how their investment pattern differ from and are similar to the internationals. In particular, it will be interesting to know what are the relationships with the state. Two, more research is needed on the emerging area of struggles related to water rights and in what ways they are similar to or different from struggles about land. Three, Rural-urban migration, resulting from water and land grab, is yet to be studied.

Four, questions of investor swindling within the class of investors are not well known. Five, there is the important issue of hierarchy between regional (e.g., AU) and global development bodies (e.g., $\mathrm{UN}$ ) as they grope to find ways of addressing the concerns with land and water grabbing, with their many voluntary guidelines. Six, the 'eco friendly' motive of buying large expanse of land for conservation purposes requires frank analysis. Is it consistent with values of social justice to commodify nature's gifts for sale, before saving them? If so, what kinds of property rights should indigenous people retain on such 'enclosures'? Finally, there is the crucial issue of how to make economics, especially land economics, education critical and hence relevant to the tensions and contradictions enveloping the water and land question.

\section{CONCLUSION}

Fred Pearce' The Land Grabbers and Tony Allan and his colleagues' the Handbook of Land and Water Grabs in Africa are as yet the most comprehensive onestop-shop accounts of the global phenomenon of land and water grabbing. Collectively, they illuminate the pace and places, perpetrators, procedures, problems, and proposals for attending a more sustainable world. They are a must read for people who are interested in eco justice, development, land use and planning, and political economy of the global order, either as general readers, practitioners, activists, teachers, students, consultants, or policy makers. Those interested in the global economic crises who have, to date, focused on the meltdown of financial markets need to read these books to see how far is the contagion and how wide are its impacts. Further, the books give material to stimulate future research in the areas of domestic, urban and rural based water and land grab, the hierarchies of power between regional and global political economic organisations, struggles with, for, and about the phenomenon, and, the contradictions in investment, as investors rush to make big agrarian profits. Even more fundamentally, the book raises the need for a re-engagement with the marginal (ised) sub discipline of land economics, why 
it ought to be made more critical, and the continuing expansion and improvement of tools and lenses of political economy on a world scale. For all these reasons, these books are highly recommended.

\section{BOOKS REVIEWED}

Fred Pearce, 2012, The Land Grabbers: The New Fight Over Who Owns the Earth, Beacon Press, Boston, 326 pp. ISBN 978-0-8070-0324-4.

Tony Allan, Martin Keulertz, Suvi Sojamo, and Jeroen Warner (Eds.), 2013, Handbook of Land and Water Grabs in Africa: Foreign Direct Investment and Food and Water Security, Routledge, London, 488 pp. ISBN 978-1-85743-669-3.

\section{REFERENCES}

Henk Bakker, 2011, Food Security in Africa and Asia: Strategies for Small-scale Agricultural Development, Cabi, Oxfordshire.

Borras S.M Jr. and Franco J.C., 2012, 'Global land grabbing and trajectories of agrarian change: A preliminary analysis', Journal of Agrarian Change, vol. 12, no.1, pp. 34-59.

Friedmann H, 1982, 'The Political Economy of Food: The Rise and Fall of the Postwar International Food Order', American Journal of Sociology, vol. 88, Supplement: Marxist Inquiries: Studies of Labor, Class, and States, pp. S248-S286.

Dubbeling M, Zeeuw H.D, and Veenhuizen V.R., 2010, Cities, Poverty and Food: Multi-stakeholder Policy and Planning in Urban Agriculture, RUAF, Leausden, The Netherlands.

George H, 2006 [1879], Progress and Poverty, Robert Schalkenbach Foundation, New York. International Development Law Organization and Namati, Rome and Washington D.C.

Greif, A. (1998) Historical and comparative institutional analysis. The American Economic Review, $88(2)$, pp. 80-84.

Insolvency Service, 2012, 'International bio-diesel companies, Greenleaf Global, closed down following government investigation', Press release 12 April, 2012.

Land Portal, 2012, 'To 10 investors', landportal.info/landmatrix/get-the-idea (accessed 6/7/2012)

McMichael P and Buttel F.H, 1990, 'New Directions in the Political Economy of Agriculture', Sociological Perspectives, vol. 33, no. 1, Critical Theory, pp. 89-109.

Njoh A.J, 2012, Urban Planning and Public Health in Africa: Historical, Theoretical and Practical Dimensions of a Continent's Water and Sanitation Problematic, Ashgate, London.

Polanyi K, 1954 [2001], The Great Transformation: The Political and Economic Origins of Our Time, Beacon Press, Massachusetts.

Rahman A.M, 2012, Water Security: Ethiopia-Egypt Transboundary Challenges over the Nile River', Journal of Asian and African Studies, DOI: 10.1177/0021909612438517.

Schoneveld, G, German, L, and Nutakor, E, 2011, 'Land-based investments for rural development? A grounded analysis of the local impacts of biofuel feedstock plantations in Ghana', Ecology and Society, vol. 16, n. 10.

Tuma, E. H. 1971, Economic history and the social sciences: Problems of methodology, Berkely and Los Angeles, University of California Press. 